\title{
The Four Pillars Research Program and its Evolution 1987-1998
}

"Achieving an entirely new design for retirement is every bit as necessary as consolidating the sources from which it is to be funded." Denis Kessler, Former President of the French Federation of Insurance Companies, General Manager, AXA, Paris.

"The idea of extending the portion of the older population that remains economically active (the fourth pillar), either in full or parttime employment, is a prominent issue".

Alan Walker, 1993 Report of the European Observatory "Older People in Europe: Social and Economic Policies".

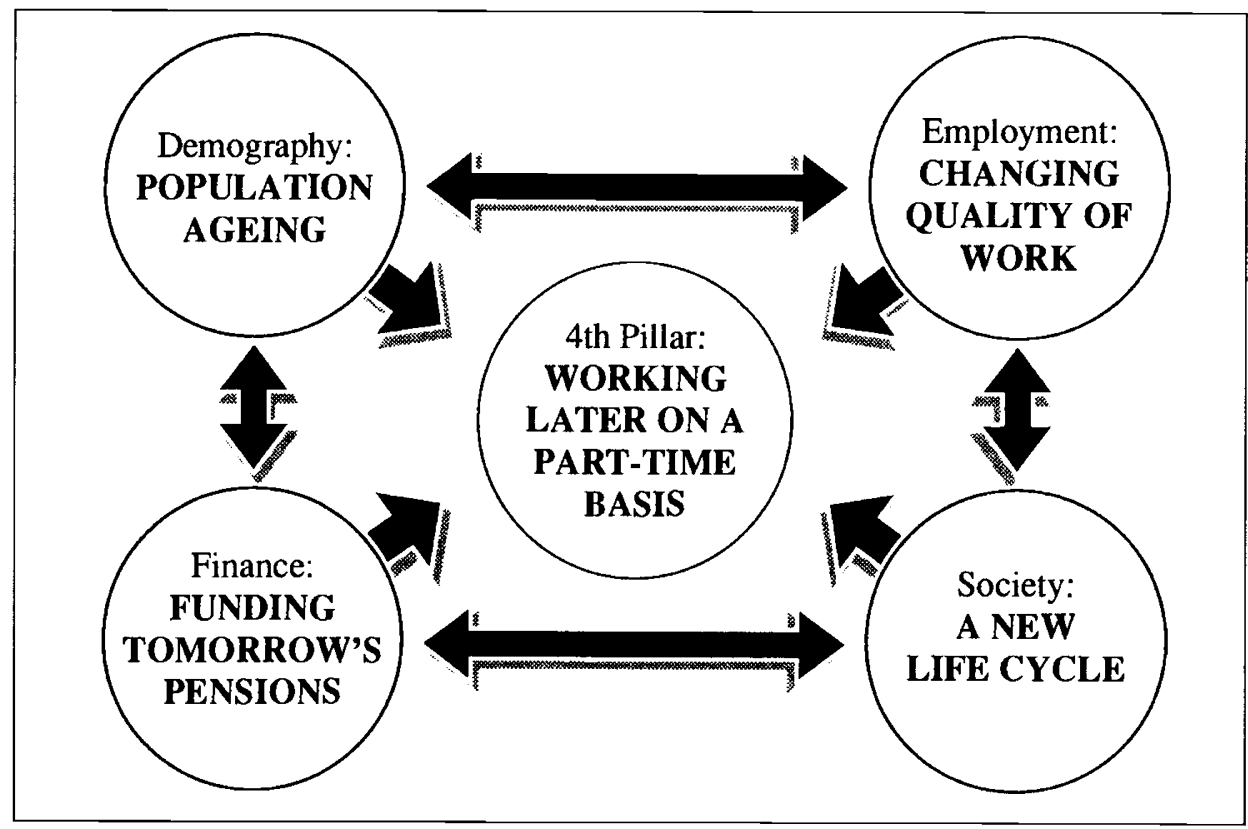




\section{The Concept of the 4 Pillars and the Research Program}

\subsection{History of the concept:}

As early as the mid-80s, the Geneva Association, conscious of changing demographic and financial trends, became concerned to assist with the crucial issue of the future financing of pensions and with rethinking some of the terms of social security. The dependency ratio of non-active retirees to the active population was about to erode rapidly and will have gone from 1 to 5 in 1990 to less than 1 to 3 in 2020. For the Association, however, demographic trends - especially increased life expectancy - could perhaps be seen as positive if only we were able to devise ways of enabling our 'ageing' populations most of whom these days enjoy good physical and mental health (P. Morniche) - to make a valid economic and social contribution to the functioning of our service economies over the decades to come.

The Association, through its work on the new service economy (PROGRES Research Program) with the new variables and paradigms associated with that economy, was able, perhaps before others, to see that these demographic and financial constraints were occurring in a new economic context where four jobs out of five are in service functions. It was also becoming widely recognised that the such service activities typically require less physical strength and greater mental abilities, which meant that, in principle, workers could easily remain productive later, especially if retirement conditions could be made more flexible and adequate continuing training, among other things, made available. This meant that the problems posed by demographics could perhaps be turned into opportunities if older workers could be kept working later on a flexible basis.

The Geneva Association was also conscious that this new challenge was about to affect the entire planet. According to the Economic and Social Council of the United Nations, 'this issue will soon be a worldwide one since in 2025 over $70 \%$ of the ageing population (60s and over) will live in the developing countries'.

Definition of Objectives: When, in 1987, it launched its research programme on Work and Retirement "The Four Pillars", the Geneva Association had therefore two main objectives:

A. To advocate consolidation of sources of pension financing: to advocate, that is, a strengthening of the 2nd pillar (occupational pensions) based on funding and to encourage development of $3 \mathrm{rd}$ pillar pensions. The intention of the Geneva Association has been that first pillar pensions should continue to have an important role for the majority of our populations, but that occupational pensions, by becoming normal, and in some cases even compulsory, practice, should be used to offset any

\footnotetext{
${ }^{1}$ The term 4th Pillar owes its origin to the fact that in most countries the funding of pensions is from resources drawn from 3 pillars:

- the first pillar is the compulsory state pension, based on the pay-as-you-go principle;

- the second pillar is the supplementary occupational pension normally based on funding, though there are exceptions to this;

- the third pillar is made up of individual savings (personal pensions, personnel assets and life insurance).
} 
relative fall in the value of 1 st pillar pensions in future decades. The Geneva Association's approach has therefore been to advise the supplementing of public social policies (one of our epoch's most significant achievements) by private insurance, and a shift in the balance between the public and private sectors by stressing the importance of developing the latter.

B. To promote the idea of a fourth pillar additional to the first three. The Fourth pillar involves supplementing the first three pillars with resources from a 4 th, that is, income from part-time work for some years after reaching retirement age or earlier in the case of early retirement. From the legal retirement age onwards, this 4th pillar income is accompanied by a partial pension. Because it helps to lighten the growing burden of funding pensions in the future, the 4th Pillar has become one answer at least to the enormous problem of pension financing in the years to come. But it also marries up with many of the changes and needs that are specific to our contemporary service economies (the increasingly flexible nature of employment and of the life-cycle).

Because of its limited means, the Geneva Association's primary purpose in this field has been to stimulate reflection among its membership, as well participating in academic and public-policy discussions, about the crucial changes affecting the first three pillars. Indeed, development of a capitalisation-based 2nd pillar, already compulsory in certain countries like the Netherlands, Switzerland and Australia, has already received the active attention of numerous international organisations, most governments (e.g. UK, the Netherlands, Nordic countries, Italy) and private insurance. This issue has already been the focus of International seminars organised at the Association's initiative or with its assistance, has received the attention of the European Commission, and has been the subject of numerous publications. Well-known social security and pension experts have contributed to the Geneva Association network on this issue. Since the early nineties, however, the Association's research programme on the 4 pillars has concentrated most of its efforts on pushing the issue of 'a new design for retirement', that is, a reexamination of the end of career and the possibility of building a 4th pillar into our social and employment policies. Given, in the meantime, new public policies for reversing the strong trend towards early retirement, the concept of the 4th pillar has had to be rethought to suit a short and medium-term frame and accordingly the Geneva Association proposed that gradual retirement become a substitute for early retirement. 


\subsection{New context, new concept: gradual retirement as a substitute for early retirement}

Indeed, the changing attitudes of stake holders towards employment at end of career have given rise, although not homogeneously across Europe, to a new consensus about a later and more flexible age of retirement and new work conditions at end of career.

- The State and its policy-makers, for well-known financial reasons, need to reverse the trend towards early retirement. Public deficits in most industrialised countries have risen enormously over the last decade and the Maastricht criteria for accession to the single currency require their drastic reduction. States are accordingly left with little alternative to limiting social protection expenditure. In recent years, policy makers have introduced new policies aimed at the inclusion of older workers:

- raising the age at which a person becomes eligible to a state pension

- drastically reducing early retirement incentives and allowances

- reducing access to disability and unemployment insurance for early retirees

- encouraging a gradual end to working life

- educating employers about the value of older workers.

- At the same time, more and more employers have realised that early-retirement policies have meant a considerable loss of experience and expertise which could have been useful to businesses, especially in training younger workers. Some employers have already realised that it makes good business sense to recruit, develop, motivate and retain older workers, and this for five main reasons: return on investment, preventing skills shortages, maximising recruitment potential, responding to demographic change, and promoting diversity (Alan Walker, 1996). Moreover employers know that they must adapt their management to an ageing work force and that career planning and employment of older workers, i.e. end-of-career management, will soon become a priority issue. More generally, it is occupational life as a whole that is being reexamined in order to adapt its cycle to the abilities and needs of the life-long worker.

- Trade unions have been in favour of early retirement especially when offered on favourable financial terms. But attitudes are now changing, since increasingly unions are becoming aware that the needs of the employee in the service economy are different from those of the worker in manufacturing and that, with entrenched ageing of the work force, continuing training and adjusted work conditions are also issues to be addressed (European Trade Union Institute, 1995).

- Older workers themselves are still fighting to secure good terms for early retirement when the latter are still available. But they are more numerous to recognise the need for a transition between a full-time career and full retirement and are more open to the idea of adjusted work conditions which enable them to remain active later. Many know that our pension systems will not be able to afford the current periods of retirement (around twenty five years or more) for much longer. Surveys have shown that there is a genuine desire among many older people for part-time or full-time work, managerial or non managerial jobs and a continuing contribution to society. Many more older workers today than ten years ago have benefited from continuing training. 


\subsection{Gradual retirement and its benefits}

Gradual retirement, often referred to as partial or part-time retirement, offers a transitional period between full-time employment and full retirement. The worker, instead of working full-time one day and fully retiring the next, can reduce work hours according to graduated and agreed schedules while drawing part-time pay (and in some cases some form of state subsidy or partial pension). Approximately five years is the transition period most commonly encountered in the OECD countries, while in recent legislation in France and Germany worktime reduction is planned for workers between 55 and 65 .

The are a number of advantages for employers and workers alike. For the employer, gradual retirement or work-time reduction:

- reduces the wage-cost of hours worked;

- raises productivity per hour (productivity per hour in many work functions increases when a worker moves from full- to part-time);

- skills and expertise together with the older worker's specific contribution are retained within the firm;

- reduces absenteeism generally high at end of career (eg. Swedish and French firms);

- increases job satisfaction whenever the firm is in a position to retain the older employee in interesting work and conserve the latter's social benefits;

- makes for better age management (filling vacated work-time with younger employees as in French firms);

- frees older workers for training duties.

For the employee, it:

- makes it possible to adapt work to the older workers's changing abilities;

- reduces stress and increases job satisfaction;

- gives the older worker the opportunity to benefit from continued membership of a work team and from inclusion in the work place (eg. Japan);

- provides the older worker with free time to develop extra-occupational activities.

Gradual retirement, it is maintained, provides a desirable opportunity as well as an efficient compromise in the conflict of interests between, on one hand, public social policy which is seeking to extend working life for well-known demographic and financial reasons, and, on the other, company employment policies, most of which are still concerned to reduce the duration of working life. The next section will show that, given reasonable levels of state financial assistance, gradual retirement can be implemented on a wide scale. Indeed, our research over the last few years has revealed the enormous potential of gradual retirement in all OECD countries to facilitate an extension of working life. By promoting work and age management at end of career, workers will be prepared to work still later and continue to contribute to pension schemes, and enterprise to reduce costs and to benefit from increased flexibility. Gradual retirement can thus be seen to serve the several aims of worker, enterprise and public-policy maker alike:

- in the short-term: a bridge between official (60/65) and effective ages of retirement $(55 / 60)$

- in the medium-term: a flexible extension of working life

- in the long-term: a model for new work patterns. 


\section{Implementation of Gradual Retirement in Selected OECD Countries}

Over recent years the Geneva Association has been able to launch a network and publish a book on Gradual Retirement in seven OECD countries and, at the same time, to publish specific country studies or articles either from members of this network or from other experts and specialists. These studies show that extension of working life is seen everywhere as a crucial policy for reducing the burden of social expenditure in years to come. Because of its flexible nature which is well suited to end of career, gradual retirement is finding increasing favour with the majority of workers, and growing acceptance with management and trade unions. In the book, a typology of four models has been proposed: the Swedish, Japanese, Continental and Anglo-Saxon models. We have space here to cite only the examples of Sweden and more recently of France and Germany.

In Sweden, gradual retirement has worked successfully for almost 20 years. In that country, labour force participation rates have decreased less than elsewhere and, in 1994, in spite of the severe recession, almost one half of workers between 60 and 65 were in some form of gradual retirement, on generous financial and professional terms. There are three main reasons why this model has been successful: availability of part-time jobs and the habit of working flexibly, a good partnership between the State and enterprise, and the high replacement rate of partial pension arrangements. In Sweden, although no direct legislation on the issue exists, there is little age discrimination compared to countries such as the UK, France or Germany. And it can be said that a culture of late and phased retirement has already been established in Sweden, even if the events of the recent past might seem to suggest otherwise. Firms, especially big ones, make impressive use of continuing training until end of career and have recently strengthened the relationship between productivity and wages. Important reforms to the pension system were introduced in June 1994. These will raise the age of partial retirement, reduce the partialpension replacement rate, and reduce the number of hours compensated. Pensions will be based on life-time earnings, furnishing an incentive to work longer. However, the flexible partial pension/part-time work scheme, being deemed too costly, is due to disappear in 2000 , leaving, as the only options available, a part-time old-age pension and a part-time disability pension, which are less attractive. Other Nordic countries have followed the Swedish model and are developing partial retirement, in particular Finland.

France, Germany and other continental European countries have been characterised by a practice of very early retirement which has been encouraged over the last two decades by public policies. It is true that labour force participation rates in these countries have reflected more the availability of generous social-security provision than the situation of labour markets. Over recent years, disability, unemployment and early retirement routes 'loopholes for those who want to retire' (W. Schmähl et al.) have been reduced significantly, but they will have to be made even less accessible and more expensive in the future.

In France, since the early nineties, but especially since 1993, government policy has attempted to reverse the early retirement trend. By providing subsidies and incentives, gradual early retirement has developed well over the last four years and has great potential. Partial early retirement is designed essentially for voluntary employees from 55 to 65 years. The employee earns a wage paid by the employer for the part-time he has worked and until retirement receives for the unworked half-time a supplement equal to 30 per cent of the daily reference wage (up to a ceiling). The income is evenly spread over the entire period 
even in cases where the half-time is worked on a pluri-annual basis. This scheme has the approval of both employer representatives and the Unions. Enterprise leaders view the scheme as an opportunity for off-loading certain categories of employee, for rejuvenating the age profile of their work force, for developing part-time throughout their staff structure and for improved management of work-force skills. The Unions and workers see it as a way of reducing work hours on favourable financial and occupational terms for flagging employees approaching end of career. Even so, gradual retirement is still frequently perceived as "second best" by comparison with early retirement which certain firms and certain sectors in difficulty have continued to enjoy. By the end of 1996 partial early retirement involved over 50,000 private-sector workers benefiting from State subsidised schemes. In 1997, it was expected that 25,000 new comers would be joining such schemes. Firms in all sectors (hospitals, building, manufacturing, services, banking and insurance) have been involved. Examples of firms having adopted gradual retirement schemes are:

- in the manufacturing sector, Rhône-Poulenc, Aérospatiale, Total, Framatome, Elf Atochem, Péchiney Emballage Alimentaire, Péchiney Rhénalu, Casino, IBM, HewlettPackard;

- in services, Crédit Agricole, AXA, UAP, many hospital and care institutions.

Gradual retirement also facilitates skills transfer and the supervision of new-comers to the work force to fill the works hours vacated by part-time gradual retirees "traineeship schemes" is the name given to such supervised apprenticeship arrangements, most frequently encountered in industry and construction. At the same time, numerous "in-firm agreements" on general work-time management have included a scheme of worktime reduction for workers at end of career, generally on favourable financial terms and without state subsidy.

In Germany, one of the key features of the law which came into force on 1 August 1996 is the promotion of part-time work for older workers providing for incentives for both employers and employees (providing the latter reduce their work hours by half on reaching 55 years). Where the employer is prepared to top up the employee's part-time earnings by $20 \%$ and pension insurance contributions to a level corresponding to $90 \%$ of full-time pay, the employee will, subject to certain conditions, be compensated for these payments by the Federal Labour Office. New collective agreements have improved the conditions of the law.

- In-company agreements now exist (VW, DB, Lufthansa, Preussen Elektra). In these companies the employees get $85 \%$ of the last salary for working half time; pension contributions are topped up to $90 \%$.

- Collective agreements exist already in a number of branches - the chemical industry, the power plant sector, insurance and elsewhere. Under such agreements, nearly 4000 employees have applied for part-time work (end of June 1997). In the chemical industry, nearly 10000 employees are expected to apply for part-time work.

- On 28 September 1997 in the IG Metal tariff area of North Würrtemberg-Nordbaden, a much needed break-through with the facilitation of part-time work for older workers was achieved. It offers the possibility of voluntary company agreements after the age of 55 and the right to part-time work after the age of 61 . Under this agreement $82 \%$ of the full-time net salary is paid and pension contributions are topped up to $95 \%$ of the fulltime gross salary (K. Kühn). 


\section{Recommendations for Public and Company Policies}

'One can hardly overstress the importance of properly integrated public and company policies for promoting the employment of older people' (I. Shimowada).

Public Policies: What stands out as essential is that public policies need to be sufficiently comprehensive and accompanied by incentives at various levels. Those countries which so far have been more successful in implementing gradual retirement tend to be the ones which have designed global policies (Sweden and Japan, and, recently, France and Germany).

- It is essential to make early retirement options as well as disability and unemployment routes more difficult, more costly and their terms more stringent. It will be objected that current labour market conditions, and especially high rates of unemployment, make any progress in the desired direction at this time very difficult. It is precisely for this reason that gradual retirement cannot be handled outside the broader context of employment redesign and redistribution.

- In several countries recent legislation (or, in the Netherlands, collective agreements) is beginning to promote replacement of full early retirement by gradual early retirement and to make retirement more flexible. But such legislation clearly needs to be accompanied by financial incentives from the State. The age at which gradual retirement can commence is also crucially important. Changing the deeply-rooted mindsets of the early retirement culture requires drastic redesign and gradual implementation. Japan seems, in this respect, to be a very good example of how to do it.

- A good partnership between the State and enterprise is vital to the development of gradual retirement and more widely of the 4 th pillar.

Company Policies: Four areas at least, among the many that require attention, should be a particular focus for this integrated policy approach:

- First, training. In order for older workers to remain motivated and productive, continuing training should not terminate at 45 or 50 years but should continue until end of career. Countries where such company policies exist are in a much stronger position when the decision to extend working life is taken. In Sweden the extent of training is impressive and there seems to be very little discrimination towards older workers (Wadensjo, 1996). In France, especially in bigger companies, the same policy is to be found (Reday-Mulvey, 1994).

- A second key variable is pay policy. It is now perfectly clear that seniority-based pay policy, by raising the wage costs of workers at end of career, constitutes a real obstacle to all forms of extension of working life. In several countries, there is a growing trend in wage calculation today towards reducing the weight of the seniority factor and increasing that of performance. In America and Britain, this trend is prevalent in bigger firms, but is now to be found in other countries (e.g. in Japan, Germany and France in some sectors, such as insurance).

- Third, occupational pensions: many Dutch, British and American pension funds are final-salary based but there is an increasing consensus to modify them and make them average-salary based. 
- And fourth, part-time and flexible work: The development of part-time and flexible forms of employment is obviously important for gradual retirement. Most countries have seen such development at either end of the life-cycle. Countries such as the Netherlands and the UK have a high rate of part-timers. Some have improved legislation in this respect so as to provide better levels of protection for part-time work (for example, France and the Netherlands). In other countries, there is availability of part-time jobs for older workers either inside (e.g. Sweden) or outside main career employment (e.g. Japan, USA, UK), but social protection for part-time employment has to be improved in the latter cases. It has been recognised by many firms that part-time work improves the productivity of older workers, reduces absenteeism and increases motivation. Examples of good initiatives for promoting part-time work in a targeted fashion are Japan's 'silver centres' or the part-time jobs in banks such as ABLE or NOWIS in the USA.

\section{Conclusion}

Gradual retirement seems to stand at the crossroad of two important issues:

- the need to extend working life for very sound reasons which have to do with the financing of pensions and the proper management of HR and skills; and

- the need to develop well-protected and regular part-time work not only as a transition from full employment to full retirement, but also as a bridge towards a socially proper division of 'full' employment whose redefinition is now long over-due.

With its research programme on The Four Pillars, The Geneva Association was able through research, seminars, publications and networking to:

- advocate maintaining 1st pillar pensions at a reasonable level

- encourage the development of 2 nd and 3 rd pillar pensions

- devise ways of making a longer working life on a flexible basis possible, that is, establishment in the long-term of a fourth pillar and in the medium term of the practice of gradual retirement.

'Is it possible due to the challenges stemming from chronic unemployment and to the potential of technology-driven productivity increases, that we are on the verge of a definition of what constitutes full time... to a point where something that is now considered part-time will be categorised as full time?... Such a policy, among others, could be salutary to the challenges of system-wide joblessness.' (H. Sheppard) 


\section{SELECTED REFERENCES}

KUHN, K. (1998), "Work Time Adjustement for Older Workers" in Career Planning and the Employment of Older Workers, Reday-Mulvey and Taylor (eds), Brussels: The European Commission (DGV).

MORNICHE, O. (1996), "Vie et santé progressent de concert", Risques, Les Cahiers de l'Assurance, no 26, avril-juin, pp. 21-22, Paris.

REDAY-MULVEY, G. (1994), "Continuing Training until End of Career", The Geneva Papers on Risk and Insurance, October, Geneva.

SCHMAHL, W., GEORGE R. and OSWALD, C. (1996), "Gradual Retirement in Germany" in Gradual Retirement in the OECD Countries, Delsen and Reday-Mulvey (eds), Aldershot (UK): Dartmouth.

SHEPPARD, H. (1996), "Gradual Retirement in the United States, Micro Issues" in Gradual Retirement in the OECD Countries, Delsen and Reday-Mulvey (eds), Aldershot (UK): Dartmouth.

SHIMOWADA, I. (1996), "Gradual Retirement in Japan, Micro Issues" in Gradual Retirement in the $O E C D$ Countries, Delsen and Reday-Mulvey (eds), Aldershot (UK): Dartmouth.

WADENSJO, E. (1996), "Gradual Retirement in Sweden" in Gradual Retirement in the OECD Countries, Delsen and Reday-Mulvey (eds), Aldershot (UK): Dartmouth.

WALKER, A. (1997), Combating Age Barriers in Employment, European Foundation for the Improvement of Living and Working Conditions, Dublin. 


\section{Seminars and Conferences}

There follows a list of the main seminars and conferences at which a paper on the Four Pillars has been presented or which we have organised ourselves during the last two years $(1996,1997)$, or are planning for 1998.

\section{6}

\section{Geneva Association Initiatives}

Press Conference on 'Gradual Retirement in the OECD Countries, Macro and Micro Issues and Policies', with an Introductory Paper by Mr Robert Anderson, European Foundation for the Improvement of Living and Working Conditions, Dublin.

February 7, 1996, Policy Studies Institute, London.

Third International Insurance Conference in Italy (Cesar and the Geneva Association), Panel on Gradual Retirement, with Professor W. Schmähl, University of Bremen.

March 14-16, 1996, Venice.

International Seminar 'The Elder in 2000' (The Geneva Association), organisation of the session on Gradual Retirement: Problems and Trends, with General Presentation on Europe, and country presentations on France, Germany, Sweden, Italy and the USA.

April 15-16, 1996, Turin.

Seminar on Employment and Insurance (The Geneva Association), Paper on Redefining End of Career Management.

May 15, 1996, London.

8th International Conference of the Society for the Advancement of Socio-Economics (SASE), Organisation of a Session on Employment Policies for Older Workers, with speakers and discussant from the OECD.

July $12-14$, Geneva.

\section{Insurer Initiatives}

Association Portuguaise des Assureurs, Conférence Le Financement Futur des Retraites dans les Pays de l'OCDE: Solutions et Perspectives pour l'Assurance.

May 14, 1996, Lisbonne.

\section{European Union Initiatives}

Forum on Long-Term Socio-Economic Forecasting, Economic and Social Committee, European Commission.

March 21-22, 1996, London.

European Workshop on Flexible and Gradual Retirement (European Commission), Chair of the Workshop on Gradual Retirement - Macro Issues.

June 20-21, 1996, Frankfurt am Main.

Conference on Population Ageing in Europe: Issues and Policies, DGV, Presentation of a paper 'The Benefits of a Flexible Extension of Working Life'.

October 25-26, 1996, Brussels.

\section{Other (USA, Sweden)}

Presentation of the book on Gradual Retirement, with Lei Delsen, at the American Association of Retired People (AARP), Washington, DC.

April 25, 1996, Washington, DC.

International Conference, National Council on Aging, Panel on Gradual Retirement in the OECD Countries, Presentation of the book and Paper on Recent Experience of Gradual Retirement in Japan and France.

April 24-27, 1996, Washington, DC.

International Conference on 'Work after 45?', National Institute for Working Life, Presentation of a paper on Gradual Retirement in the OECD Countries.

September 22-25, 1996, Stockholm. 


\section{Geneva Association Initiatives}

International Workshop on Flexibility in Employee Benefits, organised with the De Vlerick Management School, Presentation of a paper on 'Towards a Flexible Management of End-of-Career' May 26-28, 1998, Rotterdam .

Session on the Four Pillars, Strategic Issues on Insurance.

Organisation of the session with four speakers and chair of the session.

October 22, 1997, London.

\section{European Union Initiatives}

Seminars on Career Planning and Employment of Older Workers, Setting up of a action research network

June, September and November 1997, Nijmegen, Geneva, Amsterdam.

\section{Other (Germany, UK, Switzerland)}

The Utopia of Full-Time Employment, International Society for Work Options, Presentation of a paper on 'Gradual Retirement: a bridge from work to retirement and a way of redistributing employment'.

May 5-6, 1997, Berlin.

Workshop on Flexible Retirement, Employers Forum on Age, The French Scheme of Gradual Retirement.

September 4, 1997, London.

Session de Formation Continue en Gérontologie, Centre Interfacultaire de Gérontologie.

Conference sur L'Aménagement des Fins de Carrière en Europe.

October 16, 1997, Geneva.

\section{8}

\section{Geneva Association Initiatives}

International Seminar on Productive Ageing: The Future of Pensions and Health, organised in collaboration with GINA (Geneva International Network on Aging).

November 24-25, 1998, Geneva.

Organised with the DeVlerick School of Management, Seminar on Gradual Retirement.

October 1998 (date to be confirmed), Brussels.

\section{European Union Initiatives}

International Seminar on Older Workers: The Way Forward, presentation of Work Time Adjustment for Older Workers.

June 18-20, 1998, Maastricht, The Netherlands.

European Network on Ageing at Work, Second Coordination Meeting.

March 25, 1998, Brussels.

\section{Other (Belgium, Switzerland, Canada)}

Ageing of the Workforce 2000, Presentation of a paper Work-Time Adjustment for Older Workers in France - Lessons from a four-year experience (1993-97)'.

March 23-24, 1998, Brussels.

Forum sur l'Age de la Retraite,

Presentation of L'Aménagement des Fins de Carrière en Europe et en particulier en France.

April 2, 1998, Berne.

International Symposium, Restructuring Work and the Life Course.

Presentation of Adjusting Work Time at End of Career: The Transition from Full Career to Full Retirement in French Enterprise.

May 7-9, 1998, Toronto. 


\section{Recent Networks and Report}

\section{- International Network for the Book on Gradual Retirement}

With the support of the European Commission and following pioneer work by the Geneva Association in the field, a network was established at the end of 1994 on Comparative Social and Employment Policies for Older Workers and resulted in a book. The two editors made surveys in their respective countries (France and the Netherlands) and asked some of the best experts in the field to contribute:

- W. Schmähl for Germany

- E. Wadensjö for Sweden

- P. Taylor and A. Walker for the UK

- N. Takayama and I. Shimowada for Japan

- and Y-P. Chen and H. Sheppard for the USA.

\section{GRADUAL RETIREMENT IN THE OECD COUNTRIES}

L. Delsen, Nijmegen University, \& G.Reday-Mulvey, The Geneva Association, eds, Dartmouth, Aldershot, UK, 1996.

- International Network for a Report on The Age of Retirement Prepared for the OFAS (Swiss Office for Social Affairs)

In conducting a survey in pension systems (1st pillar pensions) and recent reforms in legislation, interviews were made in all $15 \mathrm{EU}$ countries and cooperation was established with the MISSOC (EU Social Security) network. The report in French is available from the Geneva Association as well as summaries in English and French.

\section{L'AGE DE LA RETRAITE DANS L'UNION EUROPEENNE \\ G. Reday-Mulvey, OFAS, Bern, 1996.}

\section{- EU Network on Older Workers 'EURO WORK AGE 1997'}

One of the two action research studies has been coordinated by Geneviève RedayMulvey (France) of the Geneva Association and Philip Taylor (UK) of the Open University. It has involved the following experts:

- Karl Kühn (Germany) on work design

- Asmund Lunde (Norway) on career planning

- Geneviève Reday-Mulvey (France) on work-time adjustment

- Maria-Luisa Mirabile (Italy) on public and company policies for older workers.

- Philip Taylor (UK) on self employment.

Its main task was to redefine clearly the concept of employment at end of career and identify success factors for implementation of positive policies. The report which will be available early 1998 identifies and examines the 3Rs: the Retention of older workers, the Reintegration of older workers and the Reinforcement of policies.

\section{CAREER PLANNING AND EMPLOYMENT OF OLDER WORKERS}

G. Reday-Mulvey \& P. Taylor, eds, EC, Brussels, 1998.

\section{- GINA (Geneva International Network on Aging)}

The Geneva Association has been a member of this network since its foundation in 1996 and, with its collaboration, is preparing for 1998 an international seminar and a publication on 'Productive Ageing: The Future of Pensions and Health'. 


\section{Geneva Association Publications on the Four Pillars: a Selected 1992-1998 Listing The Geneva Papers on Risk and Insurance}

No. 62 (January 1992): STUDIES ON THE FOUR PILLARS

- The Changing Ages of Man, Xavier GAULLIER (pp. 3-26)

- A Two Decade Comparison of Work After Retirement in the United States, Kathryn ANDERSON, Richard BURKHAUSER and George SLOTSVE (pp. 26-40)

- Ageing and the Four Pillars in Japan, Isao SHIMOWADA (pp. 40-81)

- Changing the Retirement Age in Germany, Winfried SCHMÄHL (pp. 81-104)

- The Fourth Pillar in France in the 1990's: Favourable Trends and Current Obstacles (Summary of Etudes et Dossiers no 161), Geneviève REDAY-MULVEY (pp. 104-119)

- Integration of the Disabled in the Work Process: The Dutch Policy, Lei DELSEN and Saskia KLOSSE (pp. 119-143)

- Ageing and the Costs of Health Care in the Future: The Case of Holland, G.W. de WIT (pp. 143-154).

No. 73 (October 1994): STUDIES ON THE FOUR PILLARS

- 14th Annual Lecture of the Geneva Association: Uncertainty under the Welfare State - Policy-induced Risk, Assar LINDBECK (pp. 379-393)

- Uncertainty under the Welfare State, Denis KESSLER (pp. 394-396)

- Work and Income in the Third Age - an EU Perspective, Alan WALKER (pp.397-407)

- The Role of Paid Employment for Women and Men in their 50s and 60s in the UK around the millenium and beyond, Chris TRINDER (pp. 408-432)

- Options for Extending the Working Period and Flexibilising the Transition to Retirement in the German insurance industry, Winfred SCHMAHL and Jutta GATTER (pp. 433-471)

- Research into the Work Performance of Older Employees, Peter WARR (pp. 473-480)

- Continuing Training until End-of-Career: A key Policy for the Fourth Pillar, Geneviève REDAY-MULVEY (pp. 481-489)

- Financing Long-Term Care: An Intergenerational Social Insurance Model, Yung-Ping CHEN (pp. 490-495)

- Age Discrimination Against Older Workers in the European Union, Elizabeth DRURY (pp. 496-502).

No. 81 (October 1996): STUDIES ON THE FOUR PILLARS

- Preventing Conflicts Between Generations (20th Annual Lecture), Denis KESSLER (pp 435-468)

- The Role of the Fourth Pillar in the Redesign of Social Security, Yung-Ping CHEN (pp. 469-477)

- Managing an Aging Workforce in Britain and France, Anne-Marie GUILLEMARD, Philip TAYLOR and Alan WALKER (pp. 478-501)

- Gradual Retirement in the OECD Countries: A Summary of the Main Results, Geneviève REDAY-MULVEY and Lei DELSEN (pp. 502-523)

- Gradual Retirement in Germany, Gerhard NAEGELE (pp. 524-533)

- Gradual Retirement in Italy, Angelo SCARIONI (pp. 534-553) 
- Partial Retirement and Public Policy - A Comment, Peter SCHERER (pp. 554-556)

- End to Occupational Life and Transition to Retirement: A Challenge for Swiss Institutions?, Maryvonne GOGNALONS-NICOLET, Xavier GAULLIER and Anne BARDET BLOCHET (pp. 557-574).

No (to be published in April 1999):

\section{Etudes et Dossiers}

No 166 (April 1992):

\section{STUDIES ON THE FOUR PILLARS}

- Work Place Initiatives to Retain Older Workers, Robert ANDERSON

- New End-of-Career Management in German Enterprise, Karl KUHN

- Work time Adjustment at End of Career in French Enterprise, G. REDAY-MULVEY

- Rates of Employment for Older Workers in UK Enterprise, P. TAYLOR

- Recent Reforms in Financing Pensions in Eastern Europe, Jens BASTIAN

- The Reality of Retirement in the US: Lessons in Planning for Tomorrow, Paul YAKOBOSKI

- From PAYG to Funding in Italy: a Feasible Transition?, O. CASTELLINO and E. FORNERO

- Drastic Reforms of Pensions in Nordic Countries, Eskil WADENSJÖ.

Strategic Issues and Planning in Insurance / Vol. 1

Papers from the 4th International Conference of the Geneva

Association, London, October 28-30,1992. Sessions on

"Insurance in the National economies" and "the Four Pillars":

- The role of Total Compensation and the Fourth Pillar in an Aged Society, Mitsunobu MIYAHIRA

- Employing Older Workers in the USA \& the UK, Michael C. BARTH, Terence HOGARTH \& William McNAUGHT

- Effects of German Reunification on the Demographic Conditions for Social Security, Karl-Otto KORBER

- Cross-National Patterns of Middle-Aging in a United Europe: Implications of Financial Gerontology for the Four Pillars, Neal E. CUTLER

- Demographic Ageing, Participation Rates and Part-Time Employment in Europe, Lei DELSEN

No 179 (October 1993): Studies on the Four Pillars:

- Work and Income for the Third Age in the European Community, A. WALKER (EC)

- The role for Paid Employment for Women and Men in their 50s and 60s in the UK around the millennium and beyond, C. TRINDER (UK)

- Part-Time Employment for Older Workers: Lessons from the Nordic Countries and the Netherlands, L. DELSEN (The Netherlands)

- The Myths of Early Retirement and Second Careers in the USA, P. DOERINGER (USA)

- Reading between the lines: Perspectives on Discrimination against Older Workers, R. ANDERSON

- Age and Attitudes, Main Results from a Eurobarometer Survey (ch. 1/4/5) (EC)

- The Work Performance of Older and Younger Employees, P. WARR (UK)

- Education and Training for Older Workers: a Key to the Fourth Pillar, G. REDAY-MULVEY (France)

- Training the middle-aged for new computerised technologies, J-C. MARQUIE (France)

- Work participation through appropriate training, R. CREMER (The Netherlands). 
No. 184 (May 1994):

No. 186 (July 1994):
La Retraite, l'Epargne et l'Intégration des fonds de pensions: le Cas Portugais.

Möglichkeiten zur Ausweitung der Lebensarbeitsphase und der Flexibilisierung des Übergangen in den Ruhestand in der Deutschen Versicherungswirtschaft die Derzeitige Lage und Einschätzungen für die Zukunft, Winfred SCHMÄHL and Jutta GATTER.

No. 213 bis (December 1997): L'équilibre des régimes de financement des retraites - répartition et capitalisation: le cas du Portugal, par Carlos Manuel Pereira da Silva et Fernando Ribeiro Mendes.

\section{The Four Pillars - Bulletin on the Research Program on Social Security, Insurance, Savings and Employment. (Editor: G. Reday-Mulvey)}

The following is a list of some specific contributions outside the Bulletin's regular areas:

No. 14 (May 1993):

No. 15 (January 1994):

No. 16 (June 1994):

No. 17 (January 1995):

No. 18 (November 1995):

No. 19 (July 1996):

No. 20 (December 1996):

No. 21 (July 1997):

No. 21 Bis:

No. 22 (January 1998):

No. 22 bis:
1993, the Year of Older People and Solidarity between Generations, Age and Performance.

A New Approach to End-of-Career Management.

Age Discrimination in Europe.

Changes in Work and Retirement (Japan, Austria, France, UK).

Prospects for the Fourth Pillar in Germany.

The Future of Work - Case studies in Germany and France.

Changes in Work and Retirement (EU, USA, UK, New laws).

The Trend Towards Gradual Retirement in the EU.

The Future of Work - Telework with a case study in the Netherlands. Changes in Work and Retirement (EU, Japan, UK, Sweden, Austria).

Need for Coordinating Social Security and Employment Policies.

Gradual Retirement in the OECD Countries.

Changes in Work and Retirement (EU, Switzerland, USA,

Germany...).

Gradual Retirement in Germany

The Future of Work - Good Practice for Older Workers

Changes in Work and Retirement (UK, Germany, Italy, Austria, EU, Switzerland).

When and where do Men work Part-Time?

The Future of Work - Corporations: From Caring to Re-engineering Changes in Work and Retirement (France, UK, USA, Germany, Austria...).

The Development of Pension Funds in France.

Changes in Work and Retirement (USA, Japan, Austria, France, the Netherlands, ...)

THE FUTURE OF RETIREMENT IN EUROPE - A Summary of Recent Reforms of Public (1st Pillar) Pensions, available in English and French.

Rebuilding Social Insurance - Pension Reforms in Central and Eastern Europe.

The Employment of Older Workers - European Recent Studies. Changes in Work and Retirement (European Union, Finland, USA,...) HEALTH RISK MANAGEMENT RESEARCH PROJECT: Introductory. Ideas for a Think Piece. 


\section{Think Piece on \\ HEALTH RISK MANAGEMENT}

Research project on health costs related to maintaining an active life after 60

\section{Introduction}

The financial consequences for the health and insurance sectors of the growing proportion of people in the older age groups are giving increasing cause for concern.

Aside from other key issues such as long term care, our research program focuses on the issue of improving the quality of life for the generation aged 60-80 (extended to 55-85). The number of older people able to enjoy their later years in good health has rapidly increased and continues to do so.

This is very much related to the technological advances in medicine, biological sciences and quality of life. The fact that we are currently able to replace parts of the human body and cure some illnesses will inevitably result in cost increases. On the other hand, the very same advances may enable us to reduce the same costs in the future.

\section{New Research Objectives in Health Risk Management and Practice}

Until now, research centres, economists, and health related institutions have studied the problems related to those over 60 , in terms of the following main issues:

$\Rightarrow$ Coping with the problem of increased health costs during the last two years of life. More specifically, the fact that costs incurred during this period significantly exceed payments made in preceding years of life.

$\Rightarrow$ Providing long-term care to those suffering from incapacity, a problem that has surfaced and grown to significant proportions over the last decade.

$\Rightarrow$ Another issue is the problem of a general escalation of health costs of all kinds and how best to manage them. Various studies are being conducted world-wide concerning private and public institutions facing this issue. The HMO System (Health Management Organisations and Managed Care), is an attempt to exercise greater control over the cost of all aspects of health care (hospitals, medication, personnel, etc.).

Our specific research concern is the health systems and costs related to allowing those over 60 to lead a productive and active life.

\section{Objectives of Our Research Program on Health Maintenance}

- To study the effect of advances in technology on the costs of health insurance.

- To gather statistical information on replacement surgery (such as prostheses and transplants, and some other illnesses related to cancer - for example - and heart surgery), including : 
- frequency of replacements

- patient profiles

- length of hospitalisation

- success and failure rates

- To study the evolution of Health Management Organizations in the USA and Europe.

- To explore the division between private and state insurance schemes, the obscure boundaries between worker's compensation and awards for other accidents, and their relationship to health.

- To enquire into personal experience with replacement surgery in the later stages of life, and how this relates to insurance.

- To investigate the effects on future costs of preventive measures for these types of surgical operations.

- To identify the best means of coping with the financial issues, such as how the costs can be met in various ways in different situations.

All these issues, in our program, will be related to the best maintenance systems for those age groups we have already studied in the Fourth Pillar program.

\section{Background}

There are $800^{\prime} 000$ hip operations performed world-wide per year at an estimated average cost of US\$20000 each (from the first X-ray to the moment of regained mobility). This means that approximately $\$ 16$ billion are required for these types of intervention alone. The average age of a patient requiring a hip replacement is between 55-70 (although there are exceptions) and the duration of such an implant is approximately 15 years. This type of operation has been successfully completed for over 3 decades. As life expectancy rates in Europe are increasing by 3 months annually, it seems certain that the total number of operations will increase significantly. Questions arise such as: how will this affect the finances of the health sector? Will technological advances reduce costs? If so, in which way? Who are the major decision makers regarding materials, location, and staff for the operations? How and when will technology substantially change the present situation? Previously, physicians carried much of the responsibility for this decision making process, but apparently the funding institutions are increasingly integrated into this issue.

Technological advances have shown that certain human parts may be artificially reproduced. Current research is proving that through the multiplication of cells, human cartilage can be cultivated and then implanted. This will have a significant effect on the costs and frequency of such operations in the long run. Further, it might be possible to inject cartilage so as to reinforce existing tissues, which would almost eliminate the need for these operations. Perhaps bone tissues may be reproduced as well. Such advances could have a significant impact on the health sector and on health insurance policies. 
At present hospitals account for about $50 \%$ of health costs, and so we will attempt to evaluate:

- The impact of technological advances on surgical techniques

- The reduction of stays in hospital, and the risk that fatal consequences could arise if certain patients were released prematurely

- The competence of physicians in achieving success and controlling costs

- Whether Health Management Organization systems are the best, and in which cases

- Claims patterns at successive stages of life, particularly to assess whether most claims are made in the later stages of life.

Questions for insurers that arise will be assessed, for instance: In a completely liberal market would premiums decrease significantly for the comparatively healthy younger age groups, with the exception of those whose activities are physically risky, whilst those over 55 would be obliged to pay extremely high premiums? It is clear that insurance companies, regardless of the type of institution they belong to or how they are structured, require to accumulate funds during the early periods in which premiums must be higher than average costs, so as to compensate for the later periods, otherwise premiums then would inevitably rise due to higher average costs. This, combined with the mutuality principle, is fundamental to insurance.

\section{Hypotheses on How to Meet Future Costs?}

The real problem here is how to induce people to begin saving, both individually and collectively through mutualist insurance schemes, sufficiently early in life so that funds can be constituted to compensate for excessive health maintenance costs during their later years. To what extent could such mechanisms be managed in conjunction with building up pension or retirement funds? Would this mean that for some markets in respect of certain products in given circumstances common and co-ordinated approach to life and health insurance could be adopted?

Perhaps health insurance should be linked more closely to life insurance, where a reserve capital system similar to a pension fund would be generated, which could then be available in the latter part of life. But here again, the mutuality principle still applies. Would this not consolidate the life sector reserves, savings, and capital by combining with those of the health sector in a new and more efficient way?

\section{Conferences organized in 1998}

September 24 London The Future of Medical Provision in the UK organized with JBD Developments in London

October 28-29 Paris Genetics organized in collaboration with the FFSA

November 24-25 Geneva Productive Ageing: The Future of Pensions and Health - in collaboration with GINA (Geneva International Network on Ageing) 